\title{
BRACHIOPODS OF THE LOWER CARBONIFEROUS VEGAMIÁN FORMATION (CANTABRIAN MTS, SPAIN): PART I. INTRODUCTION, LINGULIFORMEA
}

\author{
Cor F. WINKLER PRINS ${ }^{\prime}$ and María Luisa MARTÍNEZ CHACÓN \\ ' Nationaal Natuurhistorisch Museum, Postbus 9517, 2300 RA Leiden (Holanda).e-mail: winkler@naturalis.nnm.nl \\ 2 Departamento de Paleontología, Universidad de Oviedo, c/ Jesús Arias de Velasco s/n, 33005 Oviedo (España). e- \\ mail: mmchacon@asturias.geol.uniovi.es
}

Winkler Prins, C.F. and Martínez Chacón, M.L. 1999. Brachiopods of the Lower Carboniferous Vegamián Formation (Cantabrian Mts, Spain): Part I. Introduction, Linguliformea. [Braquiópodos de la Formación Vegamián (Carbonífero Inferior, Cordillera Cantábrica, España): Parte I. Introducción, Linguliformea]. Revista Española de Paleontología, $\mathbf{n}^{\circ}$ extr. Homenaje al Prof. J. Truyols, 173-183. ISSN 0213-6937.

\begin{abstract}
The history of the Tournaisian Vegamián Formation of the Cantabrian Mts (Spain) consisting of gray to black shales with a typical quiet-water ("Culm") fauna characterised by Linguliformea and small Rhynchonelliformea, is discussed. After an overview of the faunas studied thus far, an evaluation of the age of the Vegamián Formation is given, concluding to the Tournaisian, mainly middle to late Tournaisian. Also, the environment of deposition is discussed.

The linguliform fauna, discussed in this first part, is found mainly in the black, thinly bedded shales. Species of the genera "Lingula", Lachrymula and Orbiculoidea are described, including the new species Lachrymula truyolsi. The new subfamily Lachrymulinae of the Lingulidae is created for the genera Lachrymula and Trigonoglossa. It is distinguished from the Lingulinae by a relatively thick, subtriangular shell with a distinct pedicle groove and a rugose ornamentation.

The rhynchonelliform fauna, occurring mostly in more thickly bedded, often decalcified grayish layers, will be dealt with in a subsequent paper.
\end{abstract}

Keywords: Brachiopods, Linguliformea, Lower Carboniferous, Vegamián Formation, Cantabrian Mountains, Spain.

\section{RESUMEN}

La Formación Vegamián está constituida fundamentalmente por lutitas grises a negras y contiene una fauna típica de aguas tranquilas ("Culm"), caracterizada por Linguliformea y pequeños Rhynchonelliformea. En el presente trabajo se discute la historia de la formación, toda la fauna estudiada hasta el momento, la edad atribuida a la formación (concluyendo que es Turnesiense, principalmente Turnesiense medio-superior) y el ambiente de depósito. Por lo que se refiere a los braquiópodos, el trabajo se ocupa del estudio de los Linguliformea, procedentes, en su mayor parte, de lutitas negras en capas delgadas. Se describen especies de los géneros "Lingula", Lachrymula y Orbiculoidea, incluyendo la nueva especie Lachrymula truyolsi. Se crea la nueva subfamilia Lachrymulinae, dentro de los Lingulidae, en la que se incluyen los géneros Lachrymula y Trigonoglossa. La nueva subfamilia se distingue de la Lingulinae por la posesión de una concha relativamente espesa, subtriangular, con desarrollo de un surco peduncular y ornamentación rugosa.

Los Rhynchonelliformea se encuentran generalmente en capas más gruesas, grisáceas y descalcificadas; su estudio será objeto de un trabajo posterior.

Palabras clave: Braquiópodos, Linguliformea, Carbonífero Inferior, Formación Vegamián, Cordillera Cantábrica, España.

\section{INTRODUCTION}

\section{VEGAMIÁN FORMATION}

The black and grayish to cream-coloured shales of the Vegamián Formation lie, presumably with a slight disconformity, on the Ermita Formation. Deposition of the latter started at the end of the Devonian after a period of uplift resulting in a hiatus of varying length and lies therefore on formations which can be as old as Cambrian or as young as the Late Devonian. The sandstones are of varying composition, depending on the formation they 
are derived from, and they may be substituted by (bio)clastic limestones. The top part of the Ermita Formation may reach the Lower Tournaisian.

The Vegamián Formation was first described from the Cantabrian Mountains by Comte $(1959$, p. 330) as the "couches de Vegamian", although the black shales below the griotte limestones and shales (referred to as "marbre griotte", Alba Formation, or Genicera Formation) have often been mentioned in the older literature (e.g. Barrois, 1882). The type locality $\mathrm{S}$ of Vegamián has since been flooded by the Porma Reservoir and Evers (1967, p. 104, fig. 18) described a new type section higher up the mountain. Wagner et al. (1971, pp. 624-625) consider this a hypostratotype and interpret it differently, drawing the base of the Genicera Formation considerably lower, i.e. at the base of the brachiopod-bearing red and black shales with limestone nodules. A good section, rich in fossils, is found immediately below the Genicera Formation at its type section, c. $\mathbb{2} \mathrm{km} \mathrm{SW}$ of Genicera, León. This locality was completely exposed, measured and sampled by Dr R.H. Wagner and his collaborators (see Wagner, 1963; Higgins et al., 1964).

The combination of the black shales and griotte limestones and shales into one Sella Formation by Brouwer and van Ginkel (1964) was later abandoned (van Ginkel, 1965, p. 182). Also, the rather confusing usage of the Sella Formation for the top part of the Alba Formation and the combination of the Vegamián Formation with the lower part of the Alba Formation, consisting of greenish and red-coloured shales, marls and cherts, into a single Getino Formation (Rácz, 1964) was not followed. Van Staalduinen's usage (1973, p. 179) of the Vegamián Formation apparently comes close to the Getino Formation of Rácz, but one cannot be sure about his exact intentions since he does not give stratigraphic sections.

In his original description, Comte (1959, p. 330) mentions the greenish and reddish shales transitional to the griotte but describes the type section south of Vegamián as consisting of black shales with silicophosphate nodules. Wagner et al. (1971), in accordance with Winkler Prins' (1968) usage, confined the Vegamián Formation therefore to the black, sometimes greyish, shales, and included the greenish and reddish shales, with the marls and nodular limestones in the Gorgera Member of the Genicera Formation.

It should be noted that the Vegamián Formation is not everywhere found in the Cantabrian Mountains. In its southern and western flank the Baleas Limestone Formation occurs locally as a lateral replacement (Wagner et al., 1971; Truyols Santonja and Sánchez de Posada, 1983; Eichmüller and Seibert, 1984, fig. 3). The Portillas Limestone of the Picos de Europa area (Marquínez, 1978, p. 297; not to be confounded with the Portilla Formation) could be a similar replacement.

\section{FAUNAL RESEARCH}

\section{Brachiopods}

Wagner (1963, p. 54) was the first to mention the linguliform brachiopods from the Vegamián Formation, be it only at the generic level, as many did later on (Wagner, in Higgins et al., 1964, p. 221; van Adrichem Boogaert, 1967, p. 163; Winkler Prins, 1983; Martínez Chacón and Winkler Prins, 1993). These citations are not included in the synonymy lists, even though the citations of Orbiculoidea could have been included in the synonymy of $O$. cincta. Winkler Prins (1968) described the chonetid and productid brachiopods and gave a provisional list with species identifications of all brachiopods. A single brachiopod from the Picos de Europa near the road Espinama-Aliva (see Maas, 1974, p. 385) tentatively identified by the first author (C.F.W.P.) as Brachythyris sp. (cited as Brachetyra sp.) could belong to the Ermita Formation or the basal part of the Alba (= Genicera) Formation, but definitely not to the Vegamián Formation, as he suggests.

It is perhaps also interesting to mention that some fragmentary but well-preserved specimens of Orbiculoidea cincta from loc. WAG 1165B were made available to Sir Alwyn Williams for study of the shell structure by him and his group (Williams et al., 1998, p. 2021).

\section{Bivalves}

Dr R.B. Wilson (in Wagner, 1963, p. 54) gave some tentative identifications, viz. Euchondria ? cf. losseni (von Koenen) and Posidonia ? sp., (see also Winkler Prins, 1968, table I; the difference being a question of nomenclature). Amler and Winkler Prins (in press) were the first to make a detailed study of the bivalves found in the Vegamián Formation.

\section{Ammonites}

Some squashed goniatites were tentatively attributed by Mrs C.H.T. Wagner-Gentis (in Wagner, 1963, p. 54) to Pericyclus. The only well preserved ammonite found thus far was identified by her (in Wagner et al., 1971) as Muensteroceras arkansanum Gordon, 1970.

\section{Ostracodes}

Jordan and Bless (1970) described several new species of pelagic ostracodes from the Vegamián Formation and a list was given in Sánchez de Posada (1976).

\section{Trilobites}

Gandl (1973) described the trilobite faunas from the Vegamián Formation in the first of a series of papers on the Carboniferous trilobites from the Cantabrian Mountains and discussed their affinities and palaeoecological implications.

\section{Conodonts}

Fairly rich conodont faunas have been described by Higgins (in Higgins et al., 1964; Higgins, 1971) from the Genicera section and later (in Higgins and WagnerGentis, 1982) assigned to the Siphonodella cooperiPolygnathus communis Zone and the lower Scaliognathus anchoralis Zone (top part). Van Adrichem Boogaert (1967) agrees with these identifications and Raven (1983) gives some additional information, notably on conodonts belonging to the intervening G. pseudosemiglaber Zone. 

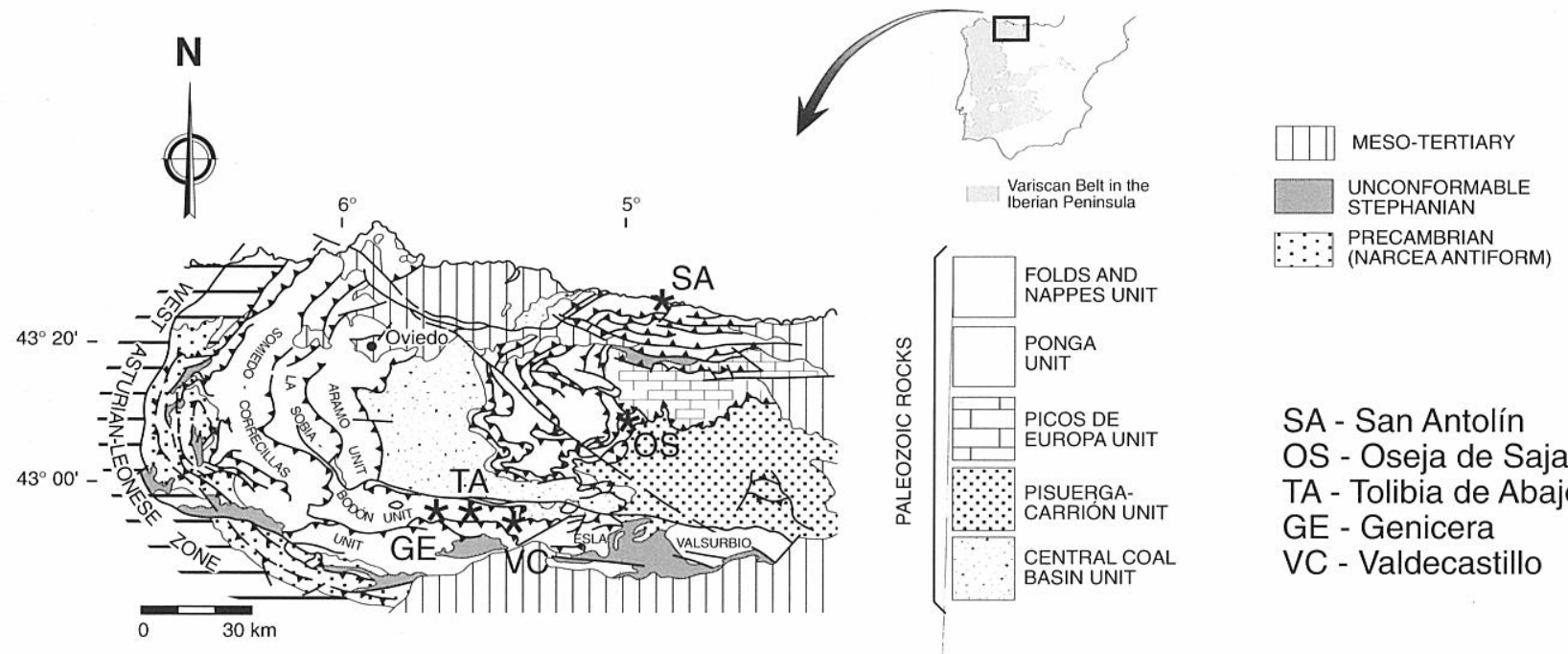

Figure 1. Simplified geological map of the Cantabrian Zone (after Julivert, 1971, modified according to the views of Pérez Estaún et al., 1988), showing the collecting localities.

\section{Other faunal elements}

Winkler Prins (1968, table I) listed radiolarians and unidentified fish remains.

\section{AGE}

Originally, the black shales of the Vegamián Formation were considered to be of a Devonian age (comparing e.g. Barrois, 1882, p. 548). There has also been some confusion with the Silurian Formigoso Formation (e.g. Llopis Lladó, 1951, see Sjerp, 1967, p. 77). Comte (1959, p. 331) links the Vegamián Formation lithologically with his Alba Formation and suggests a (late) Viséan age. De Sitter (1962, p. 258) compares it with similar shales from the Pyrenees and suggests a Tournaisian age. The goniatite fragments found in the Gildar-Montó area by Budinger and Kullmann (1964, p. 418) seem to corroborate the Viséan age, but the sandy shales are quite different from true Vegamián Shales (cf. Raven, 1983, p. 296); they are underlain by undated black shales with phosphatic nodules which appear to be typical Vegamián Shales (Wagner and Winkler Prins, personal observations). Higgins (in Higgins et al., 1964) was the first to date the Vegamián Formation reliably with the help of conodont faunas as middle-late Tournaisian, the $S$. anchoralis Zone nowadays being considered late Tournaisian. The view of van Adrichem Boogaert (1967, p. 163) that the upper and lower boundaries of the Vegamián Formation are diachronous and that its fullest development took place in the Palentian facies area is due to the fact that he included the above-mentioned sandy shales as well as cherts that are partly greenish or reddish, which should rather have been included in the overlying Alba (= Genicera) Formation. The top of the underlying Ermita Formation may vary slightly in age, but this does not mean that the age of the base of the Vegamian should also differ, since a slight hiatus is often observed. Raven (1983) agrees with a middle Tournaisian - early Viséan (S. anchoralis Zone: now late Tournaisian) age for the
Vegamián Formation. Rodríguez Fernández et al. (1985) included in the Vegamián Formation some black marly limestones with conodonts of the kockeli-dentilineatus Zone of early Tournaisian age, with intercalated black shales, which others had included in either the Ermita Formation or the Baleas Formation. The brachiopod data seem to point to a Viséan age, since they compare well with the Culm faunas from NW Europe of Viséan age (cf. Nicolaus, 1963; Winkler Prins, 1971) but a Tournaisian age cannot be excluded and the fauna is considered a better indicator for the environment (black shales) than for the age (Winkler Prins, 1968, p. 61). The goniatite Muensteroceras arkansanum Gordon, 1970 described by Wagner-Gentis (in Wagner et al., 1971) from the Genicera locality is of late Kinderhookian age perhaps ranging into the early Osagean, which could perhaps best be interpreted as middle Tournaisian. Gandl (1973, p. 30) concludes to a late Tournaisian age for the trilobite faunas. In conclusion one may state that a middle-late Tournaisian age for the Vegamián Formation is firmly established and a possible extension into the Viséan depends on whether one wants to include the sandy shales of the Montó area in it.

\section{ENVIRONMENT OF DEPOSITION}

The Vegamián Formation is generally considered a quiet-water or "Culm" deposit (e.g. Winkler Prins, 1968; Gandl, 1973; Martínez Chacón and Winkler Prins, 1993). The most likely model is a relatively shallow sea with a flat bottom with a slope of only a few degrees at the most (Winkler Prins, 1968, p. 55), which prevents wave action and thus causes a restricted environment with anaerobic bottom conditions at least most of the time (Wagner et al., 1971, p. 645). The Vegamián Formation is closely comparable with other black shale ("Culm") deposits from the Viséan of NW Europe (e.g. Dixon and Vaughan, 1911; Nicolaus, 1963).

The linguliform brachiopods are found more 


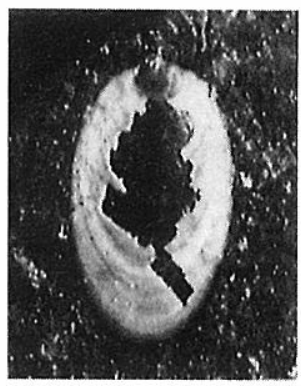

a

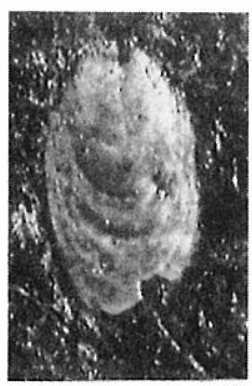

b

C

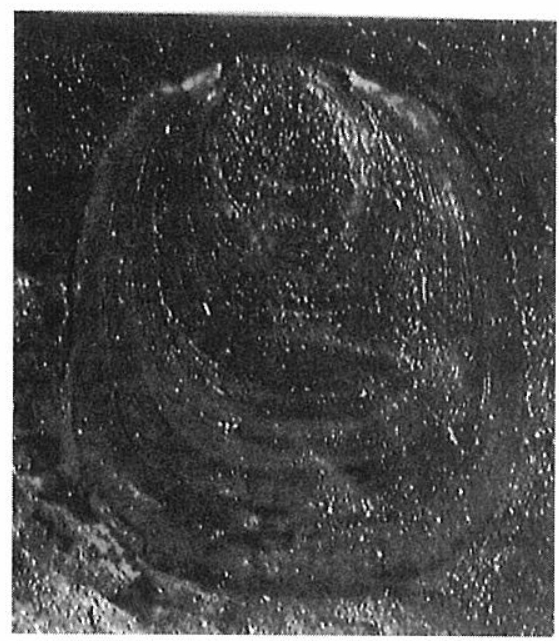

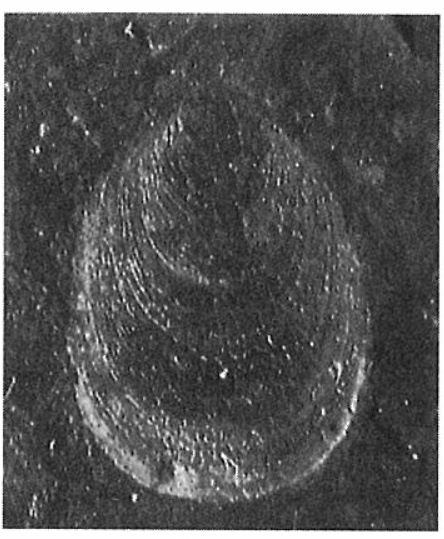

d

Figure 2. a-b. "Lingula" mytilloides J. Sowerby, 1812; Genicera, WAG 1165B; a: brachial valve, RGM 131 008, X 10; b: pedicle valve, RGM 131 009, X 10. c-d. "Lingula” squamiformis Phillips, 1836; Genicera, WAG 1165B; c: brachial valve, RGM 131 007, X 8; d: pedicle valve, RGM 293330 X 8.

commonly in the black shales, whilst the grayish to cream-coloured shales are richer in rhynchonelliform brachiopods. The latter are generally decalcified, except at the locality of Oseja de Sajambre, where the shales are siliceous.

The Vegamián Formation fits well in a sequence that started with the epeirogenetic movements that caused the hiatus, forming an angular unconformity on the map, below the Ermita Formation. The relief was levelled during the deposition of the Ermita Sandstones and a relatively shallow (c. $50 \mathrm{~m}$ ?), cool sea with a flat bottom was the result, where organic rich muds were deposited at a slow rate (Vegamián Black Shales). In shallow parts closer to the shore high-energetic limestones of the Baleas Formation were formed. When the anaerobic conditions became less extreme, the black colour changed to gray-cream and green when it was still a reducing environment, but became red under oxidising conditions (cf. Winkler Prins, 1968, p. 59). These colours are found in the overlying Genicera Formation which consists of shales, nodular limestones and cherts, still considered to have been deposited below wave base. This may indicate a shallowing of the sea as discussed by van den Bosch (1969, p. 173) on the basis of the studies by McKelvey. Sediment supply must have been very low and the region tectonically very quiet. Deposition was mainly influenced by eustatic sea-level movements. At the end of the Genicera Formation the basin started to deepen again and we see the reverse order of events: the red limestones become gray-greenish and are followed by the black, euxinic, laminated limestones of the Barcaliente Formation, which can reach a considerable thickness.

\section{COLLECTING LOCALITIES (Fig. 1)}

\section{Genicera (WAG 1165B)}

An exposure $2 \mathrm{~km} \mathrm{SW}$ of Genicera on the eastern bank of the arroyo Canalón (sheet 104, Boñar, of the geological map of Spain 1:50.000, coördinates 42 $56^{\prime} 23^{\prime \prime} \mathrm{N}$
5²9'47"W; León), dug out to measure the Vegamián Formation (see Wagner, 1963, p. 224; Higgins et al., 1964, fig. 2). Material in part collected by Dr R.H. Wagner and company (op. cit.) and partly by the first author (C.F.W.P.).

\section{Tolibia de Abajo (WP 12)}

An exposure situated c. $1500 \mathrm{~m} \mathrm{SE}$ of Tolibia de Abajo in a tributary of the Valle de Valdemaría (sheet 104, Boñar, coördinates $42^{\circ} 57^{\prime} 19^{\prime \prime} N 5^{\circ} 23^{\prime} 22^{\prime}$ 'W; León), on the east bank of the River Curueño when leaving the gorge formed by the river in the Barcaliente and Valdeteja limestones of the Bodón thrust unit (Evers, 1967). Material collected by both authors.

\section{Valdecastillo (VCO-5)}

Locality $300 \mathrm{~m} \mathrm{~W}$ of church of the village of Valdecastillo (sheet 104, Boñar, coördinates 42 54 '32'N 5¹9'W; León). Material collected by Dr J.M.G. Raven in 1981-1982 (then at Leiden Univ.) and by both authors.

\section{Oseja de Sajambre (WP 17)}

Exposure on the main road before tunnel, $1 \mathrm{~km} \mathrm{SE}$ of Oseja de Sajambre (sheet 80, Burón, coördinates 4307'34'N 501'51'”W; León). Material collected by both authors. The locality is of special interest because the shell material of the articulate brachiopods is preserved in the black siliceous shales.

\section{San Antolín (SA)}

Beach at San Antolín (sheet 31, Ribadesella, of the geological map of Spain 1:50.000, coördinates 4326'39'” 452'18"W; Asturias). Material collected mainly by the second author (M.L.M.Ch.) and Dr L. Sánchez de Posada (Univ. of Oviedo).

\section{SYSTEMATIC DESCRIPTIONS}

The main classification is based on the modern views that presumably will be used for the new edition of the 
brachiopod volume of the Treatise on Invertebrate Paleontology (cf. Holmer et al., 1995; Williams et al., 1996).

The material is deposited at the Nationaal Natuurhistorisch Museum in Leiden (prefix RGM) and at the Departamento de Geología of the Universidad de Oviedo (prefix DPO).

PHYLUM BRACHIOPODA Duméril, 1806

SUBPHYLUM LINGULIFORMEA Williams, Carlson, Brunton, Holmer and Popov, 1996

CLASS LINGULATA Gorjansky and Popov, 1985

ORDER LINGULIDA Waagen, 1885

Superfamily LINGULOIDEA Menke, 1828

Family Lingulidae Menke, 1828

Subfamily Lingulinae Menke, 1828

Genus Lingula Bruguière, 1797

Type species: Lingula anatina Lamarck, 1801 (ICZN decision 1355, see Melville, 1985).

\section{Remarks}

The genus deserves a place in the Guinness Book of Records as the longest ranging genus (OrdovicianRecent: c. $500 \mathrm{Ma}$ ). Whether all material really should be included in one and the same genus seems doubtful. Insufficient knowledge of internal structures of the older species makes assignment to Lingula often a matter of convenience, as is actually the case with the present material. Recently, new genera have been created for Mesozoic material (Lingularia Biernat and Emig, 1993) and Late Palaeozoic material (Semilingula Popov, in Egorov and Popov, 1990) based on the internal structure (muscle scars, mantle canals, etc.). Part of the Late Palaeozoic material may even belong to the Pseudolingulidae, as for example Liralingula, which is considered a junior synonym of the pseudolingulid Bicarinatina by Popov et al. (1994, p. 1217). When known, the musculature differs significantly from these genera, as is the case for the Carboniferous species " $L$." squamiformis and "L." straeleni (cf. Graham, 1970, fig. 6).

Since a detailed investigation of the internal structure of the Carboniferous species of Lingula, studying type material, is beyond the scope of this paper, we have refrained from creating a new genus for (part of) the Carboniferous species, which are provisionally referred to as "Lingula".

\section{"Lingula" mytilloides J. Sowerby, 1812} Fig. 2a-b

*1812 Lingula mytilloides J. Sowerby, 55, pl. XIX, figs. 1-2. 1934 Lingula paralella Phillips; Demanet, 15-17, text-fig. 2, pl. I, fig. 6.

?1934 Lingula elliptica Phillips; Demanet, 17-18, text-fig. 3, pl. I, fig. 7.

1938 Lingula paralella Phillips; Demanet, 54, text-fig. 22, pl. V, figs. 1-2.

1943 Lingula mytilloides Sowerby; Dorsman, 16-18, pl. 1, figs. 3-4.
1959 Lingula mytilloides Sowerby; Vangerow, 50-51, table 2, pl. 10; pl. 11, figs. 1-3, 6 .

1968 Lingula mytilloides Sow.; Winkler Prins, table 1.

1970 Lingula mytilloides J. Sowerby; Graham, 143-147, text-figs. 2-4, pl. XIV, pl. XV, figs. 1?, 9-11, pl. XX, fig. 4 (cum syn.).

1972 Lingula mytilloides Winkler Prins, in Bless and Winkler Prins, 234 (table 2).

1979 Lingula mytilloides Sow.; Korejwo, 468-469, pl. 1, figs. 1-3.

\section{Diagnosis}

Small, moderately convex "Lingula" with an elliptical outline, the anterior margin being rounded, rather than acuminate or almost straight. Length/width ratio averages 1.8 , the ratio being higher in the smaller specimens. Almost equivalve, the pedicle valve having an acuminate umbo. Ornamentation of weakly developed rugae and irregular subconcentric filae. Internally a subconcentric corrugation and fine radial striae are developed.

Material: Fourteen specimens from locality WAG 1165B: 3 collected by Dr R.H. Wagner and colleagues (see Higgins et al., 1964; RGM 142 594?, 142 654, 142 685) and 11 by the first author (C.F.W.P.; RGM 131 008-015, 020-021, 023); 3 specimens were collected by the second author from locality WP 12 (M.L.M.Ch.; DPO 33 982-984); both brachial and pedicle valves.

\section{Description}

The present material is rather small for the species, the largest specimen measuring less than $5 \mathrm{~mm}$ in length. Almost equivalve, the pedicle valve having an acuminate umbo and that of the brachial valve showing a large umbonal angle; the valves cannot always be distinguished. The shape is elliptical and the length width ratio varies between 1.5 and 2.0, the smaller specimens normally having the larger ratio. A colour-banding is observed varying from whitish to gray or light brown. The ornamentation consists of weakly developed rugae with fine subconcentric filae (growth lines?) superimposed. The internal surface shows a fine subconcentric corrugation and weakly developed radial striae. Muscle scars were not observed.

Occasionally a groove is observed on the umbonal part of some pedicle valves (Fig. 2b), similar to the ones shown for L. squamiformis by Graham (1970, pl. XVI, figs. 9, 12) and presumably due to crushing. They are also found on other parts of the valves.

Measurements (in mm):

$\begin{array}{llll}\text { Number } & \text { L } & \text { W } & \text { L/W } \\ \text { RGM 131 008 } & 2.8 & 1.5 & 1.9 \\ \text { RGM 131 009 } & 2.7 & 1.4 & 1.9 \\ \text { RGM 131 011 } & 2.8 & 1.4 & 2.0 \\ \text { RGM 131 012 } & 4.2 & 2.8 & 1.5 \\ \text { RGM 131 013 } & 3.7 & 2.2 & 1.7 \\ \text { RGM 131 020 } & 2.2 & 1.1 & 2.0 \\ \text { RGM 142 654 } & 3.8 & 1.9 & 2.0 \\ \text { RGM 142 685 } & 3.3 & 2.1 & 1.6\end{array}$




\section{Discussion}

The species has been excellently described by Graham (1970), who also designated a lectotype. He gave reasons for differentiating between " $L$." mytilloides J. Sowerby, 1812, “L." straeleni Demanet, 1934, and "L." squamiformis Phillips, 1836, which hold true for the present material. Besides, the fact that the growth lines of " $L$." squamiformis indicate that juvenile specimens have the typical shape and were not suboval clearly indicate that the two species can and should be differentiated.

The pair of diverging folds (= "radial ridges or costae" of Graham, 1970) are considered by us to have a similar function as the diverging septae of the Glottidiinae (Archbold, 1981).

\section{Occurrences}

"L." mytilloides is widely found in the Viséan-Bolsovian (ex Westphalian C) of Western Europe and in Spain it is found in the Tournaisian Vegamián Formation and may occasionally occur in younger, Pennsylvanian (= Upper Carboniferous s.l., i.e. above the mid-Carboniferous boundary; cf. Wagner and Winkler Prins, 1994) strata of the Cantabrian Mts. It is very likely that the species also occurs in the former Soviet Union, but descriptions and figures are often insufficient for a detailed comparison (e.g. Sarytcheva and Sokolskaja, 1952), so no attempt has been made to include the Soviet literature in the synonymy. Also, no comparison has been made with Carboniferous species of Lingula from other continents, since this would mean a revision of these species including the study of type material, which is outside the scope of this paper.

\section{"Lingula" squamiformis Phillips, 1836} Fig. 2c-d

\section{*1836 Lingula squamiformis Phillips, 221, pl. XI, fig. 14.}

1934 Lingula squamiformis Phillips; Demanet, 13-14, pl. I, figs. 1-3.

1943 Lingula credneri Geinitz; Dorsman, 18, pl. 1, fig. 2.

1943 Lingula squamiformis Phillips; Dorsman, 19, pl. 1, fig. 6 .

1959 Lingula aff. squamiformis Phillips; Vangerow, 53, table 2, pl. 12, fig. 1.

1968 Lingula squamiformis Phill.; Winkler Prins, table 1.

1970 Lingula squamiformis Phillips; Graham, 150, textfigs. 3, 6d, pl. XVI, figs. 5-15 (cum syn.).

?1984 Lingulipora squamiformis (Phillips); Zakowa and Chlebowski, pl. I, fig. 7.

1989 Lingula squamiformis (Phillips); Winkler Prins, B10, fig. 40.

\section{Diagnosis}

Medium-sized, weakly convex, subquadrate, thinshelled "Lingula" with a truncate anterior margin. Length/width ratio averages 1.5 . Almost equivalve, the pedicle valve being slightly extended at the umbo. Ornamentation of growth lines. Two radial folds are normally observed. Internally a fine subconcentric corrugation and radial striae are developed.
Material: Seven specimens from locality WAG 1165B: 4 collected by Dr R.H. Wagner and colleagues (see Higgins et al., 1964; RGM 142 705, 293 329-331) and 3 by the first author (C.F.W.P.; RGM 131 007, 019, 293 335); 3 specimens from loc. WP 17 (293 337; DPO 33 985) are tentatively assigned to this species.

\section{Description}

The present material is rather small for the species, the largest specimen measuring $7.6 \mathrm{~mm}$ in length. The shape is subquadrate with parallel lateral margins and a truncate (almost straight) anterior margin. Almost equivalve, the pedicle valve is slightly extended at the umbo, the brachial valve having a nearly straight posterior margin (Fig. 2c). The length/width ratio varies between 1.1 and 1.8 , averaging 1.5. A colour-banding is observed in different shades of brown and dark gray. The ornamentation consists of fine subconcentric filae (growth lines?). The internal surface shows a fine subconcentric corrugation and very weak, irregular radial striae. Muscle scars were not observed.

Measurements (in mm):

$\begin{array}{lrrr}\text { Number } & \text { L } & \text { W } & \text { L/W } \\ \text { RGM 131 007 } & 7.6 & 6.1 & 1.1 \\ \text { RGM 142 658 } & >5.7 & 4.0 & >1.4 \\ \text { RGM 293 325 } & 6.5 & 3.7 & 1.8 \\ \text { RGM 293 329 } & 6.0 & 4.0 & 1.5 \\ \text { RGM 293 330 } & 5.5 & 4.0 & 1.4 \\ \text { RGM 293 337A } & 7.5 & 4.3 & 1.7 \\ \text { RGM 293 337B } & 7.0 & 4.3 & 1.6\end{array}$

\section{Discussion}

The species has been excellently described by Graham (1970), who also gave reasons for differentiating between "L." mytilloides, " $L$." straeleni and " $L$." squamiformis (see also Discussion of " $L$." mytilloides). In our material no pair of diverging folds were observed (see Discussion of " $L$." mytilloides), but this may be due to the rather small size of our specimens, which may not have reached maturity.

\section{Occurrences}

"L." squamiformis is widely found in Viséan-Bolsovian (ex Westphalian C) deposits of Western Europe (see also "L." mytilloides). In Spain it is found in the Tournaisian Vegamián Formation of the Cantabrian Mts.

Subfamily Lachrymulinae Winkler Prins and Martínez Chacón, subfam. nov.

Type genus: Lachrymula Graham, 1970.

\section{Diagnosis}

Lingulidae characterised by relatively thick, subtriangular shells, a distinct pedicle groove and a rugose ornamentation. Internal surface smooth; septae absent.

\section{Genera included}

Lachrymula Graham, 1970 (Tournaisian-Bolsovian) 
and Trigonoglossa Dunbar and Condra, 1932 (Carboniferous).

\section{Discussion}

The outline of the Lachrymulinae resembles that of the much older Obolidae, but the latter differ in having well-developed propareas in the pedicle valves and pseudointerareas in the brachial ones. The shape, relatively thick shells, prominent rugae, and the pedicle groove distinguish the Lachrymulinae from the true Lingulinae. Whether the preservation of Lachrymulinae as white shells, in contrast to the more transparent shells of the Lingulinae, often showing colour-banding (different shades of brown to black), has any fundamental significance with regard to their shell structure is unknown at the moment.

\section{Genus Lachrymula Graham, 1970}

Type species: Lachrymula inusitata Graham, 1970 (by original designation).

\section{Diagnosis}

Rather small, tear-shaped to subovate Lachrymulinae with a weakly rugose ornamentation and faint radial striae.

\section{Species included}

Lachrymula inusitata Graham, 1970; Lingula latior McCoy, 1852; Lingula pringlei Currie, in Currie et al., 1937 and Lachrymula truyolsi sp. nov.

\section{Lachrymula truyolsi Winkler Prins and Martínez Chacón, sp. nov.} Fig. 3a-e

1993 Lachrymula aff. inusitata Graham; Martínez Chacón and Winkler Prins, pl. 1, fig. 1.

Holotype: Brachial valve (RGM 131 003; Fig. 3a).

Type locality: An exposure $2 \mathrm{~km}$ SW of Genicera (León), coördinates $51^{\circ} 31^{\prime} \mathrm{N} 4^{\circ} 21^{\prime} 57^{\prime \prime} \mathrm{W}$.

Type horizon: Fossiliferous level at $1.80 \mathrm{~m}$ above base of the Vegamián Formation (WAG 1165B, see Wagner, 1963, p. 224; Higgins et al., 1964, fig. 2).

Derivatio nominis: The species is named after Professor Jaime Truyols Santonja (Oviedo Univ.) to whom this volume is dedicated.

\section{Diagnosis}

Moderately convex Lachrymula, tear-shaped in outline, and up to almost $10 \mathrm{~mm}$ in length. L/W ratio 1.5 , greatest width anterior of mid length; pedicle valve slightly longer than the brachial one. Umbonal angle $60^{\circ}$. Ornamentation of numerous thin but prominent
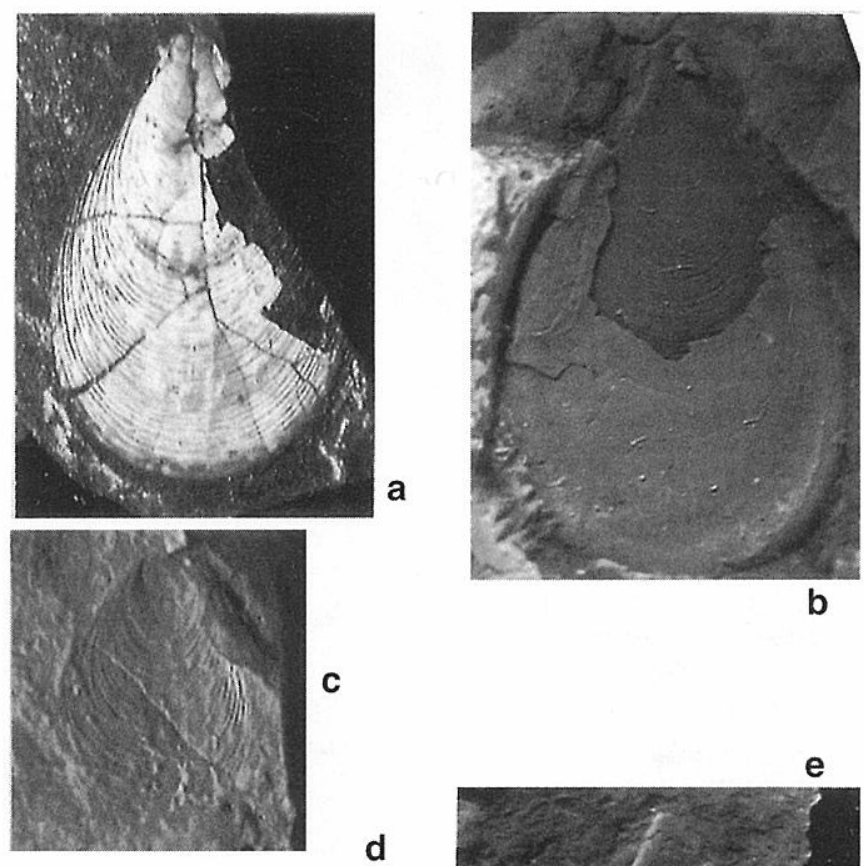

b
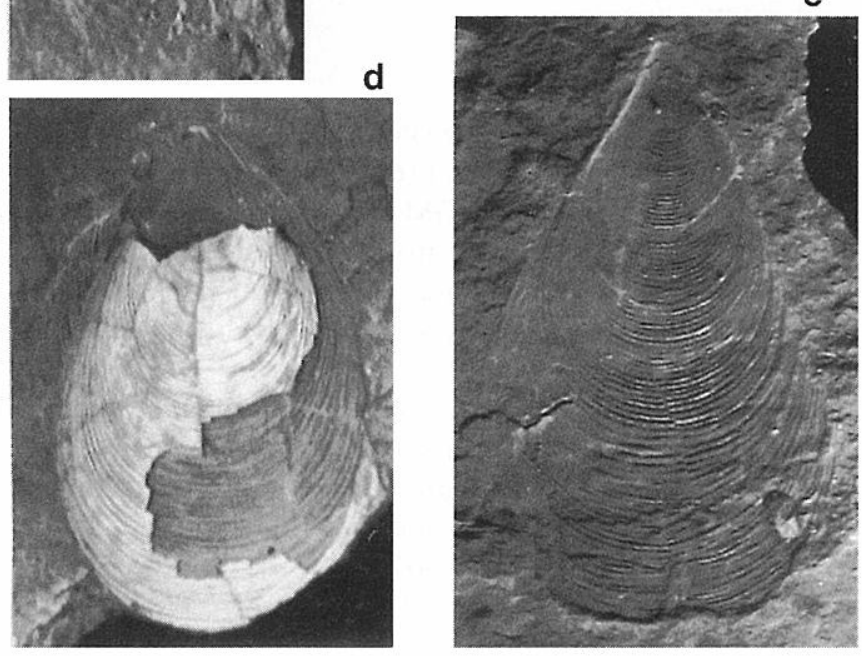

Figure 3. Lachrymula truyolsi sp. nov.; Genicera, WAG 1165B; a: brachial valve, holotype, RGM 133 003, X 8.5 ; b: fragmentary brachial valve interior, partly external mould, RGM 142 607, X 7; c: external mould of young pedicle valve, RGM 131 001, X 10.5; d: fragmentary bivalved specimen, partly as external mould, RGM 131 004, X 7; e: pedicle valve external mould, RGM 131005, X 7. b-e: Specimens whitened with magnesium oxide.

subconcentric rugae. Brachial valve with short straight posterior margin and two diverging folds. Internal surface (as far as observed) practically smooth; muscle scars not observed.

Material: Eleven specimens from locality WAG 1165B: 3 collected by Dr R.H. Wagner and colleagues (see Higgins et al., 1964; RGM 142 607, 609, 131 062) and 8 by the first author (C.F.W.P.; RGM 131 000-001, 003-007, 019).

\section{Description}

Moderately convex, tear-shaped in outline, and up to almost $10 \mathrm{~mm}$ in length. L/W ratio 1.5 , greatest width 


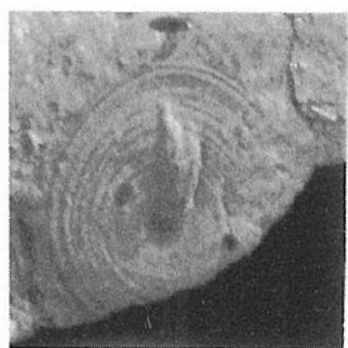

a

e

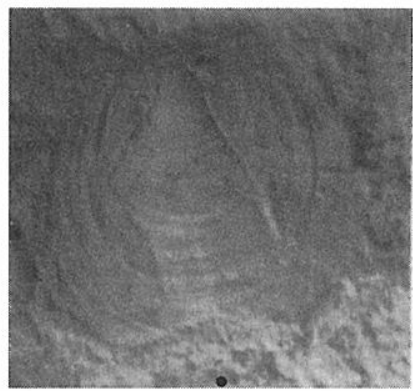

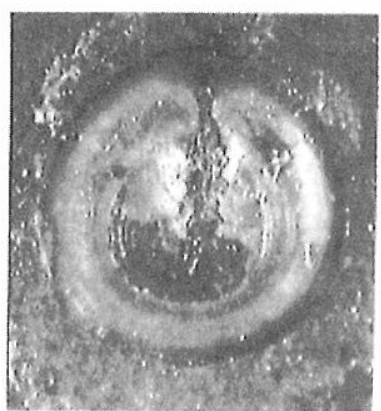

b

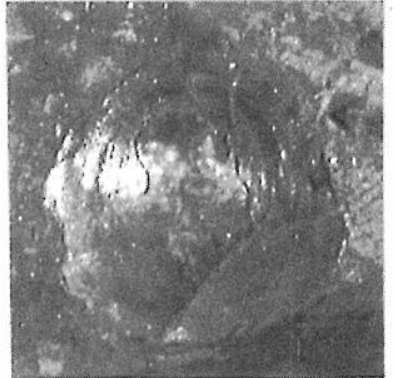

C
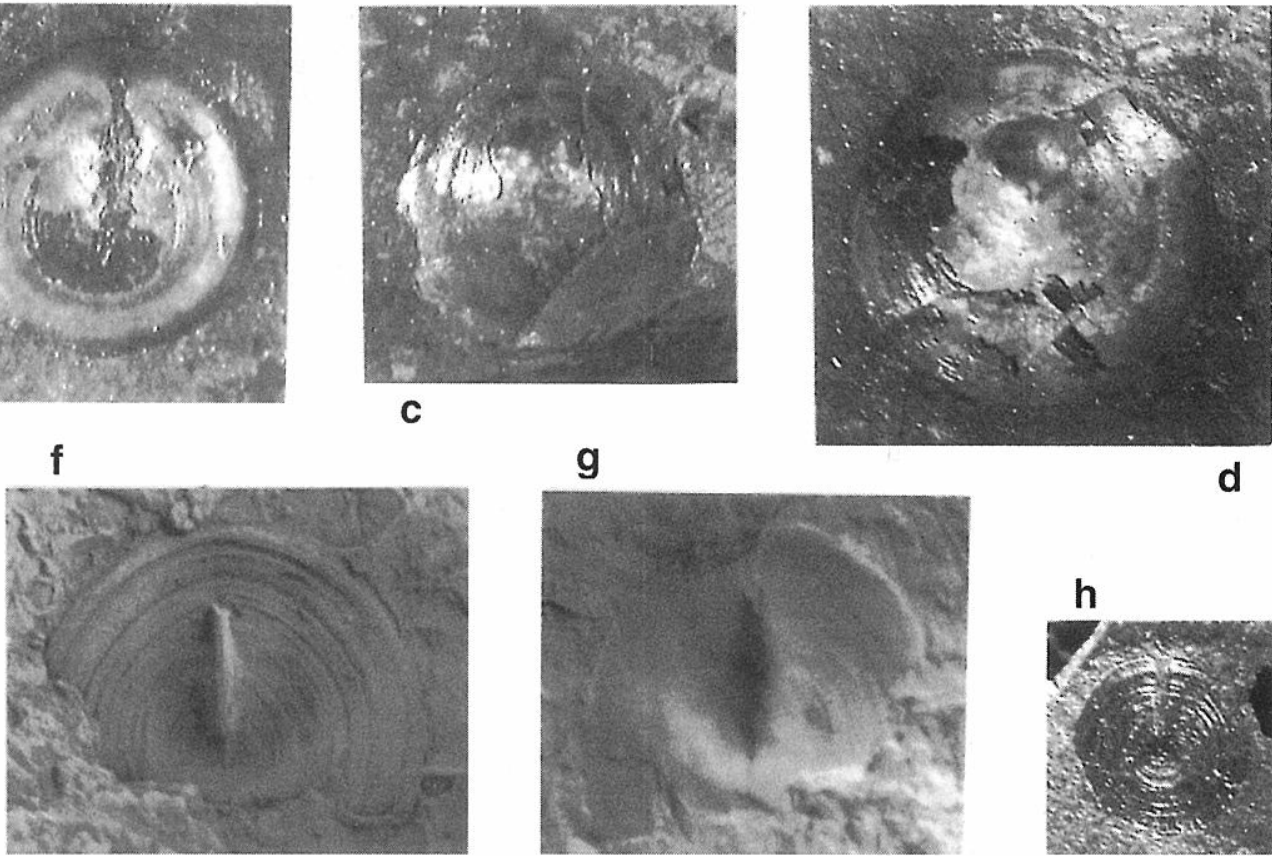

g

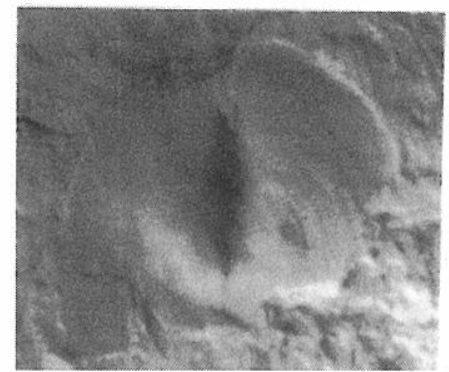

d

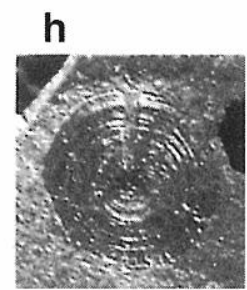

Figure 4. Orbiculoidea cincta (Portlock, 1843); a: Valdecastillo, WP 15, pedicle valve, external view, RGM 293 338, X 10. bh: Genicera, WAG 1165B; b: pedicle valve interior, RGM 293 333, X 8; c: brachial valve internal mould with some shell fragments, RGM 293 342, X 8; d: brachial valve interior, RGM 293 326, X 8; e: brachial valve interior mould showing diverging grooves from umbo, RGM 293 327, X 10; f: partial view of pedicle valve external mould, DPO 33 975, X 10; g: idem, internal mould, X 10; h: pedicle valve external mould with open pedicle slit at margin, RGM 131 031, X 10. e-g: Specimens whitened with magnesium oxide.

anterior of mid length; pedicle valve slightly longer than the brachial one, the latter with short straight hinge and two diverging folds. Umbonal angle $60^{\circ}$. Ornamentation of numerous thin but prominent subconcentric rugae.

One specimen (RGM 142 607, Fig. 3b) shows a partially preserved interior, which is smooth except for some faint markings; part with muscle scars not preserved.

\section{Measurements (in $\mathrm{mm}$ ):}

$\begin{array}{lrrr}\text { Number } & \text { L } & \text { W } & \text { L/W } \\ \text { RGM 131 001 } & 2.8 & 1.9 & 1.5 \\ \text { RGM 131 003 } & 5.9 & 3.7 & 1.6 \\ \text { RGM 131 004 } & 8.2 & 5.5 & 1.5 \\ \text { RGM 131 005 } & 9.4 & 5.6 & 1.7 \\ \text { RGM 131 005A } & 7.5 & 5.0 & 1.5 \\ \text { RGM 131 006 } & >7.0 & 5.0 & >1.4 \\ \text { RGM 131 007 } & 1.8 & 1.3 & 1.4 \\ \text { RGM 142 607 } & 8.7 & 5.4 & 1.6\end{array}$

\section{Discussion}

Lachrymula truyolsi is distinguished from the closely comparable L. inusitata from the Viséan of Scotland by its well developed posterior hinge and pair of diverging radial folds in the brachial valve.

An interesting feature is the preservation of the material of Lachrymula truyolsi as white shells, contrary to the Lingula shells which often show concentric colour bands of different shades of brown or gray. This could be due to the rather thick shells and characteristic for Lachrymula but we are not sure whether this holds also true for the Scottish material (cf. Graham, 1970, pl. XVIII, figs. 6, 7, 10, versus pl. XIV, figs. 5-6).

Occurrence: Type locality only.

Superfamily DISCINOIDEA Gray, 1840

Family Discinidae Gray, 1840

Subfamily Orbiculoideinae Schuchert and LeVene, 1929

Genus Orbiculoidea d'Orbigny, 1847 (synonym: Lingulodiscina Whitfield, 1890)

\section{Orbiculoidea cincta (Portlock, 1843)} Fig. 4a-h

1843 Orbicula cincta Portlock, 446, pl. 32, figs. 15-16 (fide Graham, 1971).

1843 Orbicula Davreuxiana de Koninck, 306, pl. XXI, fig. 4. 1934 Orbicula Davreuxiana de Koninck; Demanet, 21, pl. I, figs. 10-11; text-fig. 4 (cum syn.).

1963 Orbiculoidea newberryi marshallensis (Girty); Nicolaus, 145, pl. 9, fig. 2.

1968 Orbiculoidea sp.; Winkler Prins, table 1.

1971 Orbiculoidea cincta (Portlock); Graham, 49, pl. III, figs. 1-3; pl. IV, figs. 1-3; pl. V, figs. 7-9 (cum syn.).

1971 Orbiculoidea cf. cincta (Portlock); Graham, 50, pl. III, figs. 4-5.

\section{Diagnosis}

Plano-convex, subcircular Orbiculoidea with a distinct concentric ornamentation, consisting of growth 
lines and some more prominent rugae which may have a lamellose aspect in the pedicle valve.

Material: Thirty-two specimens from locality WAG 1165B: 8 collected by Dr R.H. Wagner and colleagues (see Higgins et al., 1964; RGM 142 601-604, 658, 705, 707) and 24 by the first author (C.F.W.P.; RGM 131 019, 021, 024-027, 029-033, 035/6, 039-740, 063, 066, 293 326-328, 332-335); seven specimens collected by the second author from locality WP 12 (M.L.M.Ch.; DPO 33 975-971); four specimens collected by Dr J.M.G. Raven from locality WP 15 (RGM 293 338-340); both brachial and pedicle valves.

\section{Description}

Both valves are essentially subcircular, small for the species (1-5 $\mathrm{mm}$ in diameter). The pedicle valve is flat with a distinct pedicle groove which is closed at the margin in mature specimens (Fig. 4a, b, f, g) but appears open at the margin in juvenile specimens (Fig. 4h). The concentric rugation is in part weakly developed, no more than growth lines, but stronger rugae are intercalated having a lamellose aspect in some mature specimens (Fig. 4f). Internally the surface is practically smooth showing some rugae and fine radial striae, especially near the margin. The brachial valve is conical with a somewhat posteriorly placed umbo. Ornamentation of weakly developed growth lines with some stronger ones, but less strongly developed than in the pedicle one. Internally the surface is smooth with faint radial striae near the margin (Fig. 4d) and some specimens showing very thin ridges diverging from the umbo (Fig. 4e).

Measurements (in $\mathrm{mm}$ ):

$\begin{array}{lcc}\text { Number } & \text { Diameter } & \text { Valve } \\ \text { RGM 131 020 } & 2.5 & \text { pv } \\ \text { RGM 131 021 } & 2.5 & \text { bv } \\ \text { RGM 131 025 } & 3.6 & \text { pv } \\ \text { RGM 131 026 } & 3.0 & \text { pv } \\ \text { RGM 131 027A } & 1.1 & \text { pv } \\ \text { RGM 131 027B } & 3.6 & \text { bv } \\ \text { RGM 131 028 } & 2.0 & \text { pv } \\ \text { RGM 131 030 } & 4.1 & \text { bvi } \\ \text { RGM 131 033 } & 1.2 & \text { pv } \\ \text { RGM 142 602A } & 2.4 & \text { pv } \\ \text { RGM 142 602B } & 1.0 & \text { pv } \\ \text { RGM 142 604 } & 4.8 & \text { bvi } \\ \text { RGM 142 658 } & 3.3 & \text { bv } \\ \text { RGM 142 707 } & 2.0 & \text { bvi } \\ \text { RGM 293 331 } & 2.0 & \text { pve } \\ \text { RGM 293 332 } & 2.5 & \text { bvi } \\ \text { RGM 293 333 } & 3.6 & \text { pvi } \\ \text { RGM 293 335A } & 5.0 & \text { pvi } \\ \text { RGM 293 335B } & 2.0 & \text { pv } \\ \text { RGM 293 336 } & 1.0 & \text { bv } \\ \text { RGM 293 338 } & 2.8 & \text { pv } \\ \text { RGM 293 339 } & 3.0 & \text { pv } \\ \text { RGM 293 340 } & 2.1 & \text { bv } \\ & & \end{array}$

\section{Discussion}

The development of the concentric ornamentation is variable in our material (even at one and the same locality), as it appears to be in Graham's (op. cit.), with some pedicle valves showing a strong, almost lamellose rugation (Fig. 4f) whilst in other material it is only weakly developed. There appears to be a gradual transition to Graham's O. cf. cincta (cf. Graham, 1971, pl. III, figs. 3-4), which is compared by him with $O$. davreuxiana de Koninck (op. cit., p. 50). We include the material attributed to the latter species in our synonymy, the more so while the paratype figured by Demanet (1934, text-fig. 4) is closely comparable to our material. Our species is characterised by its subcircular shape and conical pedicle valve with an only slightly eccentric umbo.

This poses the question whether $O$. cincta or $O$. davreuxiana has priority. Demanet (op. cit.) gives 1842 as the date of publication of de Koninck's species, whilst Graham gives (correctly) 1843, the publication itself having been published between 1842 and 1844 (pp. 241480 in 1843). Since Portlock's species was published in 1843, the exact date of publication of both species is essential to decide which has priority. We have so far been unable to obtain the necessary information on this issue, and have left $O$. cincta as the valid species following Graham (op. cit.).

\section{Occurrences}

$O$. cincta occurs widely in the Tournaisian-Bolsovian (ex Westphalian C) of NW Europe and is found in Spain in the Vegamián Formation.

\section{ACKNOWLEDGEMENTS}

The authors wish to thank Drs A. Cuesta Fernández and C. Aramburu-Zabala (Universidad de Oviedo) for their help in preparing the figures and to Drs A. Márquez Aliaga (Universidad de Valencia) and F. García Joral (Universidad Complutense de Madrid) for their helpful comments. M.L.M.Ch. acknowledges the projects (DGICYT) PB 941337 and IR-98515-1 (University of Oviedo) for financial support. The paper is a contribution to PICG's project 421.

\section{REFERENCES}

Adrichem Boogaert, H.A. van 1967. Devonian and Lower Carboniferous conodonts of the Cantabrian Mountains (Spain) and their stratigraphic application. Leidse Geologische Mededelingen, 39, 129-192.

Amler, M.R.W. and Winkler Prins, C.F. (in press). Lower Carboniferous bivalves from the Cantabrian Mts (Spain). Scripta Geologica, 120.

Archbold, N.W. 1981. Lingula (Lingulidae, Brachiopoda) from the Late Artinskian (Permian), Carnarvon Basin, Western Australia. Proceedings Royal Society of Victoria, 92, 169-180.

Barrois, Ch. 1882. Recherches sur les terrains anciens des Asturies et de la Galice. Mémoire de la Société Géologique du Nord, 2 (1), 1-630, pls 1-20.

Biernat, G. and Emig, Ch.C. 1993. Anatomical distinctions 
of the Mesozoic lingulide brachiopods. Acta Palaeontologica Polonica, 38, 1-20.

Bless, M.J.M. and Winkler Prins, C.F. 1972. Paleoecology and paleogeography of the Aegir Marine Band and its equivalents in North-western Europe. Compte Rendu VII Congrès International de Stratigraphie et de Géologie du Carbonifère, Krefeld, 1971, 1, 231-239.

Bosch, W.J. van den 1969. Geology of the Luna-Sil region, Cantabrian Mountains (NW Spain). Leidse Geologische Mededelingen, 44, 137-225, map and sections.

Brouwer, A. et Ginkel, A.C. van 1964. La succession carbonifère dans la partie méridionale des Montagnes Cantabriques (Espagne du Nord-Ouest). Compte Rendu $V$ Congrès International de Stratigraphie et de Géologie du Carbonifère, Paris, 1963, 1, 307-319.

Budinger, P. und Kullmann, J. 1964. Zur Frage der Sedimentationsunterbrechungen im Goniatiten- und Conodonten-führenden Oberdevon und Karbon des Kantabrischen Gebirges (Nordspanien). Neues Jahrbuch für Geologie und Paläontologie, Monatshefte, 1964, 414-429.

Comte, P. 1959. Recherches sur les terrains anciens de la Cordillère Cantabrique. Memorias del Instituto Geológico y Minero de España, 60, 1-440, map.

Currie, E.D., Duncan, C. and Muir-Wood, H.M. 1937. The fauna of Skipsey's Marine Band. Transactions of the Geological Society of Glasgow, 19, 413-453.

Demanet, F. 1934. Les Brachiopodes du Dinantien de la Belgique, Premier volume: Atremata, Neotremata, Protremata (pars). Mémoires du Musée Royal d'Histoire Naturelle de Belgique, 61, 1-116, pls I-X.

Demanet, F. 1938. La Faune des Couches de passage du Dinantien au Namurien dans le synclinorium de Dinant. Mémoires du Musée Royal d'Histoire Naturelle de Belgique, 84, 1-201, pls I-XIV.

Dixon, E.E.L. and Vaughan, A. 1911. The Carboniferous succession in Gower (Glamorganshire), with notes on its fauna and conditions of deposition. Quarterly Journal of the Geological Society of London, 67, 477-571.

Dorsman, L. 1943. The marine fauna of the Carboniferous in The Netherlands. Mededeelingen van de Geologische Stichting, C, IV, 3 (3), 3-101, pls 1-11.

Dunbar, C.O. and Condra, G.E. 1932. Brachiopoda of the Pennsylvanian System in Nebraska. Nebraska Geological Survey, 5, 2 ser., 377 pp., 44 pl.

Eichmüller, K. und Seibert, P. 1984. Faziesentwicklung zwischen Tournai und Westfal D im Kantabrischen Gebirge (NW-Spanien). Zeitschrift der deutschen geologischen Gesellschaft, 135, 163-191.

Egorov, A.N. i Popov, L.E. 1990. Novyj rod lingulid iz nizhnepermskikh otlozhenij Sibirskoj platformy. Paleontologicheskij Zhurnal, 1990 (4), 111-115 (English transl.: A new genus of the Lingulida from Lower Permian deposits of the Siberian Platform. Paleontological Journal, 24, 107-112).

Evers, H.J. 1967. Geology of the Leonides between the Bernesga and Porma rivers, Cantabrian Mountains, NW Spain. Leidse Geologische Mededelingen, 41, 83-151, map and sections.

Gandl, J. 1973. Die Karbon-Trilobiten des Kantabrischen
Gebirges (NW-Spanien), 1: Die Trilobiten der Vegamián-Schichten (Ober-Tournai). Senckenbergiana lethaea, 54, 21-63.

Ginkel, A.C. van 1965. Spanish Carboniferous fusulinids and their significance for correlation purposes. Leidse Geologische Mededelingen, 34, 171-225, encl.

Graham, D.K. 1970. Scottish Carboniferous Lingulacea. Bulletin of the Geological Survey of Great Britain, 31, 139-184.

Graham, D.K. 1971. A review of the brachiopod genus Orbiculoidea in the Scottish Carboniferous. Bulletin of the Geological Survey of Great Britain, 38, 43-58.

Higgins, A.C. 1971. Conodont biostratigraphy of the Late Devonian-Early Carboniferous rocks of the south central Cantabrian Cordillera. Trabajos de Geología, Universidad de Oviedo, 3 (The Carboniferous of Northwest Spain, Part I), 179-192.

Higgins, A.C. and Wagner-Gentis, C.H.T. 1982. Conodonts, goniatites and the biostratigraphy of the earlier Carboniferous from the Cantabrian Mountains. Palaeontology, 25, 313-350.

Higgins, A.C., Wagner-Gentis, C.H.T. and Wagner, R.H. 1964. Basal Carboniferous strata in part of northern León, NW. Spain: stratigraphy, conodont and goniatite faunas. Bulletin de la Société Belge de Géologie, Paléontologie et Hydrologie, 72, 205-248 (Spanish transl.: Estratos basales del Carbonífero en el norte de León. Estratigrafía y faunas de conodontes y goniatites. Notas y Comunicaciones del Instituto Geológico y Minero de España, 79 (1965), 5-54).

Holmer, L.E., Popov, L.E., Bassett, M.G. and Laurie, J. 1995. Phylogenetic analysis and ordinal classification of the Brachiopoda. Palaeontology, 38, 713-741.

Jordan, H. y Bless, M.J.M. 1970. Nota preliminar sobre los ostrácodos de la Formación Vegamián. Breviora Geológica Astúrica, 14 (4), 37-44.

Julivert, M. 1971. Décollement tectonics in the Hercynian Cordillera of northwest Spain. American Journal of Science, 270, 1-29.

Koninck, L.G. de 1842-1844. Description des animaux fossiles qui se trouvent dans le terrain Carbonifère de Belgique, vol. 1-2. P. Bertrand, Paris, 650 pp.

Korejwo, K. 1979. Biostratigraphy of the Carboniferous sediments from the Wierzchowo area (Western Pomerania). Acta Geologica Polonica, 29, 457-473.

Maas, K. 1974. The geology of Liébana, Cantabrian Mountains, deposition and deformation in a flysch area. Leidse Geologische Mededelingen, 49, 379-465, map and sections.

Marquínez, J.L. 1978. Estudio geológico del sector SE de los Picos de Europa (Cordillera Cantábrica, NW de España). Trabajos de Geología, Universidad de Oviedo, 10, 295-308.

Martínez Chacón, M.L. and Winkler Prins, C.F. 1993. Carboniferous brachiopods and the palaeogeographic position of the Iberian Peninsula. Compte Rendu XII Congrès International de Stratigraphie et de Géologie du Carbonifère et du Permien, Buenos Aires, 1991, 1, 573-580.

McCoy, F. 1852. Contributions to British Palaeontology: On 
some new Brachiopoda from the Carboniferous Limestone. Annals and Magazin of Natural History (2), 10, 421-429.

Melville, R.V. 1985. Opinion 1355 Lingula anatina Lamarck, 1801 is the Type Species of Lingula Bruguière, (1797) (Brachiopoda). Bulletin of Zoological Nomenclature, 42, 332-334.

Nicolaus, H.J. 1963. Zur Stratigraphie und Fauna der crenistria-Zone im Kulm des Rheinischen Schiefergebirges. Beihefte zum Geologischen Jahrbuch, 53, 1-246.

Pérez-Estaún, A., Bastida, F., Alonso, J.L., Marquínez, J., Aller, J., Álvarez Marrón, J., Marcos, A. and Pulgar, J.A. 1988. A thin-skinned tectonics model for an arcuate fold and thrust belt: the Cantabrian Zone. Tectonics, 7, 517537.

Phillips, J. 1836. Illustrations of the Geology of Yorkshire; or a description of the strata and organic remains: accompanied by a geological map, sections, and diagrams, and figures of the fossils. Part II. The Mountain Limestone district. J. Murray, London, xx + 253 pp., 25 pls.

Popov, L.E., Blodgett, R.B. and Anderson, A.V. 1994. First occurrence of the genus Bicarinatina (Brachiopoda, Inarticulata) from the Middle Devonian in North America (Alaska). Journal of Paleontology, 68, 1214-1218.

Rácz, L. 1964. Carboniferous calcareous algae and their associations in the San Emilano and Lois-Ciguera formations (Prov. León, NW Spain). Leidse Geologische Mededelingen, 31, 1-112, map.

Raven, J.G.M. 1983. Conodont biostratigraphy and depositional history of the Middle Devonian to Lower Carboniferous in the Cantabrian Zone (Cantabrian Mountains, Spain). Leidse Geologische Mededelingen, 52, 265-339.

Rodríguez Fernández, J.R., García-Alcalde, J.L. y Menéndez-Alvarez, J.R. 1985. La sucesión del Devónico superior y Carbonífero inferior en el Sinclinal de Alba (León, N.O. de España). Compte Rendu X Congrès International de Stratigraphie et de Géologie du Carbonifère, Madrid, 1983, 1, 133-144.

Sánchez de Posada, L.C. 1976. Quelques remarques au sujet de la répartition des faunes d'Ostracodes carbonifères dans la Chaîne Cantabrique. Annales de la Société Géologique du Nord, 96, 407-412.

Sarytcheva, T.G. i Sokolskaja, A.N. 1952. Opredelitel' paleozojskikh brakhiopod Podmoskovnoj kotloviny. Trudy Paleontologicheskogo Instituta Akademiya Nauk SSSR, 38, 1-307, pls. 1-71. (French transl.: Guide de détermination des Brachiopodes paléozoïques de la dépression de Moscou. Traduction S.I.G., 1814, 1-322, pls., tables, figs.).

Sitter, L.U. de 1962. The structure of the southern slope of the Cantabrian Mountains; explanation of a geological map with sections. Scale 1:100,000. Leidse Geologische Mededelingen, 26, 255-264.

Sjerp, N. 1967. The geology of the San Isidro-Porma area (Cantabrian Mountains, Spain). Leidse Geologische Mededelingen, 39, 55-128, map and sections.

Sowerby, J. 1812-1815. The Mineral Conchology of Great
Britain, vol. 1, B. Meredith, London, vii + 234 pp., 102 pls.

Staalduinen, C.J. van 1973. Geology of the area between the Luna and Torío rivers, southern Cantabrian Mountains, NW Spain. Leidse Geologische Mededelingen, 49, 167205, map and sections.

Truyols Santonja, J. y Sánchez de Posada, L. 1983. El Carbonífero inferior y medio de la Región de Pliegues y Mantos. In: Carbonífero y Pérmico de España (Coord. C. Martínez Díaz). Instituto Geológico y Minero de España, Madrid, 39-59.

Vangerow, E.F. 1959. Die Fauna des westdeutschen Oberkarbons, I: Die inarticulaten Brachiopoden des westdeutschen flötzführenden Oberkarbons. Palaeontographica, A, 113, 36-60.

Wagner, R.H., 1963. A general account of the Palaeozoic rocks between the rivers Porma and Bernesga (León, NW. Spain). Boletín del Instituto Geológico y Minero de España, 74, 171-334.

Wagner, R.H. and Winkler Prins, C.F. 1994. General overview of Carboniferous stratigraphy. Annales de la Société géologique de Belgique, 116 (1993), 163-174 (for erratum see: ibidem, 118 (1995), 161).

Wagner, R.H., Winkler Prins, C.F. and Riding, R.E. 1971. Lithostratigraphic units of the lower part of the Carboniferous in northern León, Spain; with a Note on some goniatite faunas by C.H.T. Wagner-Gentis. Trabajos de Geología, Universidad de Oviedo, 4 (The Carboniferous of Northwest Spain, Part II), 603-663, 3 pls.

Williams, A., Carlson, S.J., Brunton, C.H.C., Holmer, L.E. and Popov, L. 1996. A supra-ordinal classification of the Brachiopoda. Philosophical Transactions of the Royal Society London, B, 351, 1171-1193.

Williams, A., Cusack, M. and Buckman, J.O. 1998. Chemico-structural phylogeny of the discinoid brachiopod shell. Philosophical Transactions of the Royal Society London, B, 353, 2.005-2.038.

Winkler Prins, C.F. 1968. Carboniferous Productidina and Chonetidina of the Cantabrian Mountains (NW Spain): systematics, stratigraphy and palaeoecology. Leidse Geologische Mededelingen, 43, 41-126, 8 tables, 9 pls.

Winkler Prins, C.F. 1971. Connections of the Carboniferous brachiopod faunas of the Cantabrian Mountains (Spain). Trabajos de Geología, Universidad de Oviedo, 4 (The Carboniferous of Northwest Spain, Part II), 685-692.

Winkler Prins, C.F. 1983. A general review of the Carboniferous brachiopods from the Cantabrian Mountains (North Spain). In: Contributions to the Carboniferous geology and palaeontology of the Iberian Peninsula (Ed. M.J. Lemos de Sousa). Faculdade de Ciências Universidade do Porto, 69-91.

Winkler Prins, C.F. 1989. Brachiopoden, 2. Gea, 22(4), B916 (in Dutch).

Zakowa, H. i Chlebowski, R. 1984. Nowe dane o karbonie w okolicy Bolechowic i Kowali (Góry Swietokrzyskie). Kwartalnik Geologiczny, 28, 317-340.

Manuscrito recibido: 15 de enero, 1998 Manuscrito aceptado: 24 de septiembre, 1998 